Birkhäuser 


\section{The Chile-2015 (Illapel) Earthquake and Tsunami}

Edited by

Carla Braitenberg

Alexander B. Rabinovich

Previously published in Pure and Applied Geophysics (PAGEOPH), Volume 173, No. 2, 4-7, 2016 and Volume 174, No. 1 and 3, 2017 


\section{Editors}

\section{Carla Braitenberg}

Department of Mathematics and Geoscience

University of Trieste

Trieste

Italy
Alexander B. Rabinovich

Institute of Ocean Sciences

Department of Fisheries and Oceans

Sidney

Canada

and

P.P. Shirshov Institute of Oceanology

Russian Academy of Sciences

Moscow

Russia

ISBN 978-3-319-57821-7

ISBN 978-3-319-57822-4 (eBook)

DOI 10.1007/978-3-319-57822-4

Library of Congress Control Number: 2017940365

Mathematics Subject Classification (2010): 86-XX, 86-06, 86A17, 76-XX

(C) Springer International Publishing AG 2017

This work is subject to copyright. All rights are reserved by the Publisher, whether the whole or part of the material is concerned, specifically the rights of translation, reprinting, reuse of illustrations, recitation, broadcasting, reproduction on microfilms or in any other physical way, and transmission or information storage and retrieval, electronic adaptation, computer software, or by similar or dissimilar methodology now known or hereafter developed.

The use of general descriptive names, registered names, trademarks, service marks, etc. in this publication does not imply, even in the absence of a specific statement, that such names are exempt from the relevant protective laws and regulations and therefore free for general use.

The publisher, the authors and the editors are safe to assume that the advice and information in this book are believed to be true and accurate at the date of publication. Neither the publisher nor the authors or the editors give a warranty, express or implied, with respect to the material contained herein or for any errors or omissions that may have been made. The publisher remains neutral with regard to jurisdictional claims in published maps and institutional affiliations.

Cover illustration taken from Tang, L., Titov, V.V., Moore, C. et al. Pure Appl. Geophys. (2016) 173: 369. doi:10.1007/s00024-015-1226-3

Cover design: deblik, Berlin

Printed on acid-free paper

This book is published under the trade name Birkhäuser (www.birkhauser-science.com)

The registered company is Springer International Publishing AG

The registered company address is: Gewerbestrasse 11, 6330 Cham, Switzerland 


\section{Preface}

The Peru-Chile subduction zone, where the Nazca Plate subducts beneath the South American Plate, is one of the most active seismic zones on the Earth. The Great Chilean (Valdivia) Earthquake with the moment magnitude $M_{\mathrm{W}} 9.5$ occurred in this zone on 22 May 1960. The earthquake was the strongest ever instrumentally recorded; modern estimates demonstrate that almost $25 \%$ of the total global seismic energy released between 1906 and 2005 was related to the Great Chilean earthquake. The 1960 Chilean earthquake was a milestone in modern seismological and seismotectonic research. Many hundreds of scientific papers were written on this event, initiating tremendous progress in our understanding of the earth processes responsible for producing large megathrust earthquakes. Even now, 57 years after the earthquake, studies of this event continue bringing new scientific results. Among related effects, the earthquake generated strong global free oscillations of the earth, a phenomenon that had been predicted theoretically at the time. The theory revealed to be correct, and in 1960 the first experimental proof of the earth oscillations was given from observations from strainmeters, tilt meters and long period seismographs.

The great international interest to the 1960 event is related to the trans-Pacific catastrophic tsunami also generated by the earthquake. The great Chilean tsunami of 22 May 1960 struck the nearby coast of Chile about 15-20 min after the main earthquake shock; 1,655 people were killed by the tsunami, approximately 3,000 injured and almost 2,000,000 displaced. Propagating across the Pacific Ocean, approximately $15 \mathrm{hrs}$ later, tsunami waves reached the Hawaiian Islands and killed 61 people. Then around 22-24 hrs after the earthquake, the tsunami waves arrived at the Pacific coasts of the Philippines, Japan, and Russia; 142 people lost their lives in Japan and 32 more in the Philippines. The high degree of destruction and loss of life in a number of the Pacific countries located far away from the source strongly stimulated international cooperation in tsunami research and mitigation, and resulted in the establishment of the International Coordination Group for the Tsunami Warning System in the Pacific (ICG/ITSU, at present ICG/PTWS).

The Chilean subduction zone had been relatively silent since 1960, but recently a sequence of great tsunami generating earthquakes ruptured the megathrust near the 1960 rupture zone. The earthquakes are the 27 February $2010\left(M_{\mathrm{W}} 8.8\right), 1$ April $2014\left(M_{\mathrm{W}} 8.2\right)$ and 16 September $2015\left(M_{\mathrm{W}} 8.3\right)$ shocks. The tsunamis affected the entire Pacific Ocean and reached large amplitudes for certain coastal populated areas across the Pacific, similar to what occurred during the Chile 1960 event.

During the fifty years that separated the 1960 event with the onset of the recent sequence, the 2004 Sumatra tsunami occurred, which was the most catastrophic tsunami in human history. This event initiated a major upgrade of the existing network of coastal tide gauges and strongly stimulated development of the Deep-ocean Assessment and Reporting of Tsunamis (DART) system and some other systems of tsunami measurements in the open ocean. As a result, the 2010, 2014 and 2015 tsunamis have been recorded by hundreds of high-quality coastal and deep-ocean instruments throughout the entire Pacific Ocean. At the same time, enormous progress in measuring seismicity and strain rate in space and time along subduction zones was achieved, allowing the determination of deformation rates and an understanding of rupture processes on the fault system that makes up the entire South American subduction zone.

Naturally, relatively strong seismic events regularly took place in Chile, but none of these events had a magnitude comparable to the 1960 earthquake. The event of 27 February 2010, a magnitude $M_{\mathrm{W}}$ 8.8 thrust-fault earthquake, occurred near the coast of Central Chile. The epicenter of the earthquake was located offshore from the Maule region and the earthquake became known as the "Maule earthquake". The source area of the 2010 Chilean earthquake was located immediately to the north of the rupture zone of the 1960 Great Chilean Earthquake. The 2010 earthquake was one of the most powerful earthquakes in human history and the largest in the Southern Hemisphere since 1960. In addition 
to causing major destruction throughout central Chile and killing several hundred people, the 2010 earthquake generated tremors that were felt in many Argentinean cities, and in southern Peru.

Four years later, on 1 April 2014, a new great thrust earthquake with moment magnitude $M_{\mathrm{W}} 8.2$ occurred off the coast of northern Chile. The epicenter was located $70 \mathrm{~km}$ from Iquique and approximately $1,600 \mathrm{~km}$ north from the epicenter of the 2010 Chile earthquake. The earthquake generated a major tsunami with the maximum run-up of $4.6 \mathrm{~m}$ on the coast closest to the earthquake epicenter. Tsunami waves were observed throughout the entire Pacific Ocean but no noticeable damage was reported except the coast of Chile. Nevertheless, the event attracted considerable scientific interest.

As the final, third event in a tragic symphony of great Chilean earthquakes, a destructive $M_{\mathrm{W}} 8.3$ ( $M_{\mathrm{W}} 8.4$ by some estimates) earthquake occurred on 16 September 2015. The epicenter of the earthquake was located offshore, $48 \mathrm{~km}$ west of Illapel, central Chile, and $480 \mathrm{~km}$ north from the epicenter of the 2010 Maule earthquake. The earthquake generated a major trans-Pacific tsunami that strongly affected the coast of Chile with the maximum run-up of $13.6 \mathrm{~m}$ and was recorded by numerous coastal tide gauges and open-ocean DART stations. Tsunami waves created severe damage on the near-source coast of central Chile and killed 15 people. The unprecedented mass evacuation of over one million people from the coastal zone prevented a much higher death toll.

In response to this tragic event, Pure and Applied Geophysics (PAGEOPH) announced a Topical Collection of papers "Chile-2015" and opened a "hot-line" for prospective manuscripts. The main focus was on the 2015 event, but the invitation encompassed previous great Chilean earthquakes and tsunamis. The activity of scientists was very high and a great many papers illustrating the earthquake and tsunami studies were submitted.

The twenty-two papers are presented here in a volume that describes the Illapel, Chile 2015 earthquake $\left(M_{\mathrm{W}} 8.3\right)$ and tsunami from various aspects including the source rupture and comparison with the observations, using seismologic, geodetic, hydrologic and oceanographic data, giving an excellent documentation of the effects that such a big event generates.

The rupture of the fault is determined with different models and inversion techniques that aim at explaining near field seismograms and teleseismic worldwide observations as well as geodetic GNSS and InSar observations. The geodetic observations allowed scientists to determine the complete permanent surface deformation of the 2015 earthquake. Apart from the seismologic observations, amplitudes of spheroidal mode free oscillations recorded in a network of superconducting gravimeters were also used to estimate the seismic moment.

The tsunami coastal run-up and tide gauge observations provided additional constraints on the rupture models based on seismic records. Near real time modeling of tsunami generation was very effective, and many lives were saved by incorporating real time seismographic records and data from open-ocean instruments into tsunami forecast models, resulting in only 7 minutes of elapsed time between initiation of the earthquake and the tsunami warning.

The earthquake was also observed by water level variations of aquifers as far as the Russian platform, and in a transient anomaly of the magnetic field across Brazil. The GNSS networks addressed the problem of defining the mechanism limiting the extent of rupture during fault break by investigating interseismic coupling. Highly coupled segments correlate with source regions of the Chilean large earthquakes. Furthermore, satellite gravity observations provided evidence that topographic highs on the subducting oceanic plate was a controlling factor in limiting rupture, such that rupture along fault is greatest between areas subducting oceanic relief.

The collection of papers from researchers and worldwide institutions demonstrates the great attention that the South American Chilean subduction margin has garnered. The precise documentation of the broad spectrum of phenomena that are caused or affected by the earthquake rupture is essential to improve risk reduction of populations exposed to earthquake hazards in this region. Great progress has been achieved to be able to issue earthquake communication bulletins with accurate information on the epicenter location and expected damage in real time, and tsunami warnings even ahead of the time the tsunami wave hits populated areas. The next step is to develop methods that allow issuing warnings ahead of the arrival of the seismic wave causing destruction. 
The editors of this volume would like to strongly acknowledge Clemens Heine (Executive Editor Mathematics/Applied Sciences, Birkhäuser/Springer-Verlag), Renata Dmowska (PAGEOPH Editorin-Chief, Topical issues), Eric Geist (PAGEOPH Editor, Atmospheric and Ocean Sciences) and many other PAGEOPH editors who strongly supported the preparation of this volume and helped with editing of the corresponding papers.

Carla Braitenberg University of Trieste, Italy

Alexander B. Rabinovich Institute of Ocean Sciences Department of Fisheries and Oceans Sidney, Canada and

P.P. Shirshov Institute of Oceanology Russian Academy of Sciences Moscow, Russia 


\section{Contents}

Preface $\ldots V$

A Review of Source Models of the 2015 Illapel, Chile Earthquake and Insights from

Tsunami Data

Kenji Satake and Mohammad Heidarzadeh

2017, 174, No.1, Pages 1-9, DOI: 10.1007/s00024-016-1450-5.

Rapidly Estimated Seismic Source Parameters for the 16 September 2015 Illapel, Chile $\boldsymbol{M}_{\mathbf{w}} \mathbf{8 . 3}$ Earthquake

Lingling Ye, Thorne Lay, Hiroo Kanamori and Keith D. Koper

2016, 173, No.2, Pages 321-332, DOI: 10.1007/s00024-015-1202-y .

Rupture Process During the 2015 Illapel, Chile Earthquake: Zigzag-Along-Dip Rupture Episodes Ryo Okuwaki, Yuji Yagi, Rafael Aránguiz, Juan González and Gabriel González

2016, 173, No.4, Pages 1011-1020, DOI: 10.1007/s00024-016-1271-6.

Imaging Rupture Process of the 2015 Mw 8.3 Illapel Earthquake Using the US Seismic Array

Bo Li and Abhijit Ghosh

2016, 173, No.7, Pages 2245-2255, DOI: 10.1007/s00024-016-1323-y

Interseismic Coupling, Megathrust Earthquakes and Seismic Swarms Along the Chilean

Subduction Zone $\left(3^{\circ}-18^{\circ} \mathrm{S}\right)$

M. Métois, C. Vigny and A. Socquet

2016, 173, No.5, Pages 1431-1449, DOI: 10.1007/s00024-016-1280-5

Low-Frequency Centroid Moment Tensor Inversion of the 2015 Illapel Earthquake from Superconducting-Gravimeter Data

Eliška Zábranová and Ctirad Matyska

2016, 173, No.4, Pages 1021-1027, DOI: 10.1007/s00024-016-1252-9.

Coseismic Fault Slip of the September 16, 2015 Mw 8.3 Illapel, Chile Earthquake Estimated from InSAR Data

Yingfeng Zhang, Guohong Zhang, Eric A. Hetland, Xinjian Shan, Shaoyan Wen and Ronghu Zuo 2016, 173, No.4, Pages 1029-1038, DOI: 10.1007/s00024-016-1266-3

Analysis of the Illapel $\mathbf{M w}=8.3$ Thrust Earthquake Rupture Zone Using GOCE-Derived Gradients

Orlando Álvarez, Agustina Pesce, Mario Gimenez, Andres Folguera, Santiago Soler and Wenjin Chen

2017, 174, No.1, Pages 47-75, DOI: 10.1007/s00024-016-1376-y

\section{Chile2015: Lévy Flight and Long-Range Correlation Analysis of Earthquake}

\section{Magnitudes in Chile}

Maria P. Beccar-Varela, Hector Gonzalez-Huizar, Maria C. Mariani, Laura F. Serpa and

Osei K. Tweneboah

2016, 173, No.7, Pages 2257-2266, DOI: 10.1007/s00024-016-1334-8 
Time-Based Network Analysis Before and After the $\boldsymbol{M}_{\boldsymbol{W}} \mathbf{8 . 3}$ Illapel Earthquake 2015 Chile

Denisse Pastén, Felipe Torres, Benjamín Toledo, Víctor Muñoz, José Rogan and

Juan Alejandro Valdivia

2016, 173, No.7, Pages 2267-2275, DOI: 10.1007/s00024-016-1335-7 . . . . . . . . . . . . . . . 123

Chilean Earthquakes: Aquifer Responses at the Russian Platform

Alina Besedina, Evgeny Vinogradov, Ella Gorbunova and Igor Svintsov

2016, 173, No.4, Pages 1039-1050, DOI: 10.1007/s00024-016-1256-5. .

lonospheric Plasma Response to $\boldsymbol{M}_{\boldsymbol{w}} \mathbf{8 . 3}$ Chile Illapel Earthquake on September 16, 2015

C. D. Reddy, Mahesh N. Shrivastava, Gopi K. Seemala, Gabriel González and Juan Carlos Baez

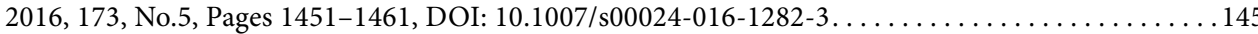

Remote Sensing of Atmospheric and lonospheric Signals Prior to the Mw 8.3 Illapel

Earthquake, Chile 2015

Mohammad Reza Mansouri Daneshvar and Friedemann T. Freund

2017, 174, No.1, Pages 11-45, DOI: 10.1007/s00024-016-1366-0 .

Chile2015: Induced Magnetic Fields on the $\mathbf{Z}$ Component by Tsunami Wave Propagation

V. Klausner, T. Almeida, F. C. De Meneses, E. A. Kherani, V. G. Pillat and M. T. A. H. Muella

2016, 173, No.5, Pages 1463-1478, DOI: 10.1007/s00024-016-1279-y. .

First Report on Seismogenic Magnetic Disturbances over Brazilian Sector

V. Klausner, T. Almeida, F. C. De Meneses, E. A. Kherani, V. G. Pillat, M. T. A. H. Muella and

P. R. Fagundes

2017, 174, No.3, Pages 737-745, DOI: 10.1007/s00024-016-1455-0

The 16 September 2015 Chile Tsunami from the Post-Tsunami Survey and Numerical Modeling Perspectives

Rafael Aránguiz, Gabriel González, Juan González, Patricio A. Catalán, Rodrigo Cienfuegos,

Yuji Yagi, Ryo Okuwaki, Luisa Urra, Karla Contreras, Ian Del Rio and Camilo Rojas

2016, 173, No.2, Pages 333-348, DOI: 10.1007/s00024-015-1225-4 . . . . . . . . . . . . . . . . 219

Field Survey of the 2015 Chile Tsunami with Emphasis on Coastal Wetland and Conservation Areas

Manuel Contreras-López, Patricio Winckler, Ignacio Sepúlveda, Adolfo Andaur-Álvarez,

Fernanda Cortés-Molina, Camila J. Guerrero, Cyntia E. Mizobe, Felipe Igualt,

Wolfgang Breuer, José F. Beyá, Hernán Vergara and Rodrigo Figueroa-Sterquel

2016, 173, No.2, Pages 349-367, DOI: 10.1007/s00024-015-1235-2

A Study of the $2015 M_{w} 8.3$ Illapel Earthquake and Tsunami: Numerical and Analytical Approaches

Mauricio Fuentes, Sebastián Riquelme, Gavin Hayes, Miguel Medina, Diego Melgar,

Gabriel Vargas, José González and Angelo Villalobos

2016, 173, No.6, Pages 1847-1858, DOI: 10.1007/s00024-016-1305-0. . .

Real-Time Assessment of the 16 September 2015 Chile Tsunami and Implications for Near-Field Forecast

Liujuan Tang, Vasily V. Titov, Christopher Moore and Yong Wei

2016, 173, No.2, Pages 369-387, DOI: 10.1007/s00024-015-1226-3 . 
Comparison Between Tsunami Signals Generated by Different Source Models and the Observed Data of the Illapel 2015 Earthquake

Ignacia Calisto, Matthew Miller and Iván Constanzo

2016, 173, No.4, Pages 1051-1061, DOI: 10.1007/s00024-016-1253-8.

Tsunami Characteristics Along the Peru-Chile Trench: Analysis of the 2015 Mw8.3 Illapel, the 2014 Mw8.2 Iquique and the 2010 Mw8.8 Maule Tsunamis in the Near-field

R. Omira, M. A. Baptista and F. Lisboa

2016, 173, No.4, Pages 1063-1077, DOI: 10.1007/s00024-016-1277-0

299

Tsunami Penetration in Tidal Rivers, with Observations of the Chile 2015 Tsunami in Rivers in Japan

Elena Tolkova

2016, 173, No.2, Pages 389-409, DOI: 10.1007/s00024-015-1229-0 